Brazilian Journal

of Chemical

ISSN 0104-6632

Printed in Brazil

Engineering

www.scielo.br/bjce

Vol. 35, No. 03, pp. 957-968, July - September, 2018

dx.doi.org/10.1590/0104-6632.20180353s20170032

\title{
EVALUATION OF DIRECT PHOTOLYSIS, ELECTROOXIDATION AND PHOTOELECTROOXIDATION FOR RHODAMINE-B DEGRADATION
}

\author{
Tatiane Benvenuti ${ }^{1,}{ }^{*}$, Adjanara Preis Gabriel ${ }^{1}$, Alan Nelson A. Heberle ${ }^{1}$, \\ Maira P.P. Lucena ${ }^{1}$, Patricia Melo Halmenschlager Petter ${ }^{1}$, Álvaro \\ Meneguzzi ${ }^{1}$ and Andréa Moura Bernardes ${ }^{1}$
}

\begin{abstract}
${ }^{1}$ Laboratório de Corrosão, Proteção e Reciclagem de Materiais - LACOR. Programa de Pós-Graduação em Engenharia de Minas, Metalúrgica e de Materiais - PPGE3M - UFRGS. Av. Bento Gonçalves, 9500, S. IV, P. 43426, S. 103. Bairro Agronomia, Zip code: 91501-970. Porto Alegre, RS - Brasil
\end{abstract}

(Submitted: January 17, 2017; Revised: October 12, 2017; Accepted: November 13, 2017)

\begin{abstract}
The focus of this study is to evaluate the efficiency of oxidation processes in the treatment of a solution containing Rhodamine- $\mathrm{B}(\mathrm{RhB})$ used in various industrial applications. The advanced oxidation processes of electrooxidation (EO) and photoelectrooxidation (PEO) were used. At the same time, direct photolysis (DP) was also applied. Total organic carbon (TOC) reduction and color removal were evaluated. There was an efficient color removal when DP was performed, and the color removal efficiency was the highest when $\mathrm{NaCl}$ was used as supporting electrolyte for PEO and EO. However, the TOC reduction was low, indicating that the degradation of the color does not correspond to the pollutant mineralization.
\end{abstract}

Keywords: Oxidation process, Rhodamine-B, Discoloration, Mineralization.

\section{INTRODUCTION}

Water pollution caused by the use of dyes is a problem to be faced because of the damage to the environment and health. Natural waters contamination can be considered as a great problem of modern societies (Martín de Vidales et al., 2016). In addition to the textile industry, one of the processes that uses a considerable amount of dyes is the dyeing of precious stones, such as agates, for jewelry and fashion accessories. Textile and stone processing are present in most countries, the application of organic dyes being an important stage of these industrial processes.
The agate-staining process with organic dyes in alcoholic solutions has a high water demand for the rinsing step of the colored agates, generating large volumes of wastewater containing complex molecules such as Rhodamine- $\mathrm{B}$ dye $(\mathrm{RhB})$ which is used to give the pink color to the stones. Rhodamine is a generic name for a family of compounds called fluorone organic dyes, molecular formula $\mathrm{C}_{28} \mathrm{H}_{31} \mathrm{~N}_{2} \mathrm{O}_{3} \mathrm{Cl}$ and molecular weight $479.02 \mathrm{~g} / \mathrm{mol}$ (Pizzolato et al., 2002). Rhodamine type dyes are generally toxic and soluble in water, methanol and ethanol (Torres et al., 2006). 
Considering the process steps associated with the colored stone production, the dyeing is the most pollutant, since the wastewater generated can change the color, $\mathrm{pH}$ and conductivity of natural water. Moreover, this wastewater generates chemical oxygen demand (COD) and biochemical oxygen demand (BOD), solubilized nutrients (for example, nitrogen and phosphorus) and can contaminate the water with metals. Still, certain classes of dyes, as well as their by-products, can be carcinogenic and/or mutagenic (Hasnat et al., 2015).

The main techniques related to wastewater discoloration involve adsorption processes (Kaur and Kaur, 2014), precipitation (Daneshvar et al., 2003), chemical (Pizzolato et al., 2002) and electrochemical degradation (Adeogun and Balakrishnan, 2015; Du et al., 2012) and photochemical biodegradation, among others (Oller et al., 2011). For organic pollutants, in addition to the previous processes, other techniques have been used, such as liquid-liquid extraction, reverse osmosis and ultrafiltration (Panizza et al., 2008). The choice of method depends not only on the cost of the process, but also on such factors as the concentration and volume of effluent. Dyes, in general, are difficult to degrade in the conventional treatments and the development of methods for dye removal assumes great importance.

In this context, direct photolysis (DP) may be used for the degradation of complex organic pollutants through a UV irradiation source, without adding chemical reagents. In the same line are the advanced oxidation processes (AOPs), that are characterized by the generation of highly reactive hydroxyl radicals (HO•) to oxidize organic compounds from wastewater (da Silva et al., 2015). Among the advantages of using AOPs, it is important to note that a complete mineralization of organic pollutants may occur. Therefore, they are considered promising methods for the degradation of organic matter and hazardous organic pollutants (Oller et al., 2011). The degradation of organic matter has been obtained by applying Fenton's reagent (Rodrigues et al., 2009), ozone (Balakrishnan et al., 2002), photocatalysis (Cavicchioli and Gutz, 2003; Golimowski and Golimowska, 1996; Wang et al., 2001), electrooxidation (Pelegrino et al., 2002; Simond et al., 1997; Szpyrkowicz et al., 2001) and photoelectrochemical techniques (Pinhedo et al., 2005; Rodrigues et al., 2008).

Electrooxidation (EO) consists of the application of potential or current density to an electrochemical cell composed of one or more pairs of electrodes. When the applied electrodes are coated with metal oxide semiconductors, known as dimensionally stable anodes (DSA), the generation of $\mathrm{HO} \bullet$ can occur during the electrolysis of water, characterizing the process as an AOP (Pelegrino et al., 2002; Simond et al., 1997; Szpyrkowicz et al., 2001). The anodic oxidation of organics may occur by electrochemical conversion and electrochemical combustion.

Research has pointed to the use of combined processes:EO assisted by heterogeneousphotocatalysis, called photoelectrooxidation (PEO). In addition to the electric source, PEO occurs in the presence of UV light on a DSA. PEO has been extensively studied for the degradation of organic contaminants (Chen et al., 2004; Du et al., 2012; Ghernaout et al., 2011; Panizza et al., 2008; Pinhedo et al., 2005).

The aim of this paper was the use of oxidative processes for the treatment of a solution containing Rhodamine-B. The investigation was based on two suppositions: 1) photoelectrooxidation could be more efficient than direct photolysis, by relying on two oxidation mechanisms: photocatalysis and electrolysis that intensify the $\mathrm{HO} \cdot$ generation, with a synergistic effect to increase the mineralization rates, and 2) $\mathrm{NaCl}$ as supporting electrolyte could improve the dye degradation by the generation of $\mathrm{ClO}^{-}$, a strong oxidant radical. Treatment time, supporting electrolytes and UV irradiation were evaluated as factors which could increase the effectiveness of these alternative treatments for dye degradation.

\section{MATERIALS AND METHODS}

The synthetic effluent was a solution containing 20 $\mathrm{mg} \mathrm{L}^{-1}$ of RhB and $10 \%$ of ethanol (both commercial grade) diluted in distilled-deionized water. This effluent was produced as a surrogate of an industrial effluent from the agate dyeing process (Massacci, 2000). The synthetic effluent had $\mathrm{pH}=7.06$, the absorbance at 554 $\mathrm{nm}$ (the RhB characteristic wavelength) was 2.5 a.u. (absorbance units) and conductivity was around 10 $\mu \mathrm{S} \mathrm{cm} \mathrm{cm}^{-1}$. In low conductivity solutions, the electrical resistance between the electrodes is very high for EO and PEO processes. This resistance may hinder the application of the necessary electric current required for the generation of hydroxyl radicals $(\mathrm{HO} \bullet)$, or can make the treatment process costly (Selcuk and Bekbolet, 2008). Therefore, it was necessary to add a supporting electrolyte.

Two different supporting electrolytes $0.6 \mathrm{~g} \mathrm{~L}^{-1}$ of $\mathrm{NaCl}$ or $\mathrm{Na}_{2} \mathrm{SO}_{4}$, analytical grade, were added to the effluent samples to give electrical conductivity and to allow the electrochemical treatment. 


\section{Electro and photoelectrooxidation tests}

The experimental system consists of an oxidation reactor that has a volume of $1.4 \mathrm{~L}$. It was built with borosilicate glass. A coupled thermostatic bath allowed the temperature control (the temperature was maintained at $30{ }^{\circ} \mathrm{C}$ during these processes). The DSA(r) electrode used as anode was a $370 \mathrm{~cm}^{2}$ titanium plate $(20 \mathrm{~cm} \times 18.5 \mathrm{~cm})$, coated with metal oxides $\left(70 \% \mathrm{TiO}_{2} / 30 \% \mathrm{RuO}_{2}\right)$. This cylindrical electrode was placed in the center of the reactor. Another cylinder of the same material was used as cathode and placed at a distance of $1 \mathrm{~cm}$ outside the anode. Fig. 1 shows the experimental system for photoelectrooxidation treatment.

The difference between the EO and PEO systems is the presence of the UV source. For the PEO process, in the center of the reactor, inside the anode cylinder, a commercial mercury vapor lamp of $125 \mathrm{~W}$ was placed. Its glass bulb was removed and replaced by a quartz tube of $5 \mathrm{~cm}$ diameter. The quartz bulb is in contact with the solution during the treatment.

Using an electrical current source for both advanced oxidative processes (EO and PEO), galvanostatic tests were performed. For these treatments, an electrical current of 0.26 A was applied, that corresponds to a current density of $0.7 \mathrm{~mA} \mathrm{~cm}^{-2}$. This value was used based on studies of Du et al. (2012), who applied 0.7 $\mathrm{mA} . \mathrm{cm}^{-2}$ in order to degrade $5 \mathrm{mg} \mathrm{L}^{-1}$ of $\mathrm{RhB}$. The treatment time was 60 minutes.

\section{Direct Photolysis}

This oxidative process (OP) was performed in another similar oxidation reactor built with borosilicate glass. It has a volume of $1.4 \mathrm{~L}$, without the temperature control system. Two different UV irradiation sources, resulting in different incident light fluxes were evaluated: 125 and $250 \mathrm{~W}$. The same quartz tube used for PEO was used to cover the UV lamp during the photolysis tests. For DP and PEO processes, the lamp was turned on 10 minutes before the treatment starts to ensure the stabilization of the UV radiation.

\section{Analytical procedures}

Samples were collected before and after treatments by oxidation processes and characterized for color removal - monitored by UV-VIS spectroscopy - and concentration of organic matter by TOC.

The analyses by UV-VIS spectroscopy were done using a T80 + UV/Vis Spectrophotometer from PG Instruments Ltd. The wavelength adopted to analyze $\mathrm{RhB}$ using the photometric method was $554 \mathrm{~nm}$ (Buranda et al., 2010).

The total organic carbon (TOC) was determined by Non-Purgeable Organic Carbon (NPOC) in a $\mathrm{CPH}$ Shimadzu TOC-L apparatus.

The irradiance of ultrapure water and of effluent samples was measured for both high-pressure commercial mercury vapor lamps (125 and $250 \mathrm{~W})$ by an Instrutherm MRUR-203 UV-C light meter. Considering that, in a well-designed bench setup, the irradiance and fluence rate are virtually the same, the fluence (UV dose) (J.m-2) was calculated as the product of fluence rate (irradiance) (W.m ${ }^{-2}$ ) and exposure time (seconds) (Bolton and Linden, 2003).

\section{Experimental procedures}

A factorial experiment planning was used to assess the effects of process variables on the degradation of RhB. Based on the method described by Montgomery (2009), the statistical evaluation was made by variance analysis (ANOVA). Assuming the following example, the factors $\mathrm{A}, \mathrm{B}$ and $\mathrm{C}$ are set; the ANOVA table is shown in Table 1 . The $F$ test on the principal effects and interactions affect directly the mean square (MS).

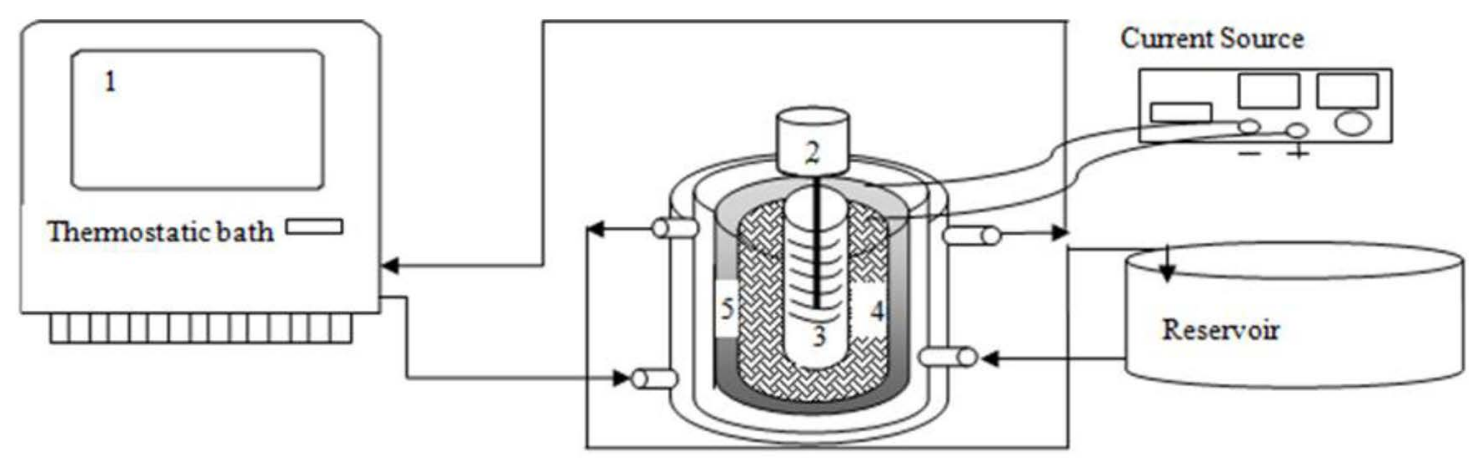

Figure 1. Photoelectrooxidation system: (1) Thermostatic bath; (2) Mercury vapor lamp; (3) Quartz tube; (4) Ti/Ru Anode; (5) Ti/Ru Cathode. 
Table 1. Analysis of variance for a three factor model (adapted from Montgomery, 2009).

\begin{tabular}{|c|c|c|c|c|}
\hline Source & Degrees of freedom & Sum of squares(SS) & Means squares(MS) & $\mathrm{F}_{\mathrm{o}}$ test \\
\hline A & $\mathrm{a}-1$ & $\mathrm{SS}_{\mathrm{A}}$ & $\mathrm{MS}_{\mathrm{A}}^{(\mathrm{a})}$ & $\mathrm{F}_{\mathrm{o}}=\mathrm{MS}_{\mathrm{A}} / \mathrm{MS}_{\mathrm{R}}$ \\
\hline B & b-1 & $\mathrm{SS}_{\mathrm{B}}$ & $\mathrm{MS}_{\mathrm{B}}$ & $\mathrm{F}_{\mathrm{o}}=\mathrm{MS}_{\mathrm{R}} / \mathrm{MS}_{\mathrm{R}}$ \\
\hline $\mathrm{C}$ & $\mathrm{c}-1$ & $\mathrm{SS}_{\mathrm{C}}$ & $\mathrm{MS}_{\mathrm{C}}$ & $\mathrm{F}_{\mathrm{o}}=\mathrm{SM}_{\mathrm{C}} / \mathrm{MS}_{\mathrm{R}}$ \\
\hline $\mathrm{AB}$ & $(a-1)(b-1)$ & $\mathrm{SS}_{\mathrm{AB}}$ & $\mathrm{MS}_{\mathrm{AB}}$ & $\mathrm{F}_{\mathrm{o}}=\mathrm{MS}_{\mathrm{AB}} / \mathrm{MS}_{\mathrm{R}}$ \\
\hline $\mathrm{AC}$ & $(a-1)(c-1)$ & $\mathrm{SS}_{\mathrm{AC}}$ & $\mathrm{MS}_{\mathrm{AC}}$ & $\mathrm{F}_{\mathrm{o}}=\mathrm{MS}_{\mathrm{AC}} / \mathrm{MS}_{\mathrm{R}}$ \\
\hline $\mathrm{BC}$ & $(b-1)(c-1)$ & $\mathrm{SS}_{\mathrm{BC}}$ & $\mathrm{MS}_{\mathrm{BC}}$ & $\mathrm{F}_{\mathrm{o}}=\mathrm{MS}_{\mathrm{BC}} / \mathrm{MS}_{\mathrm{R}}$ \\
\hline $\mathrm{ABC}$ & $(\mathrm{a}-1)(\mathrm{b}-1)(\mathrm{c}-1)$ & $\mathrm{SS}_{\mathrm{ABC}}$ & $\mathrm{MS}_{\mathrm{ABC}}$ & $\mathrm{F}_{\mathrm{o}}=\mathrm{MS}_{\mathrm{ABC}} / \mathrm{MS}_{\mathrm{R}}$ \\
\hline Residual & $a b c(n-1)$ & $\mathrm{SS}_{\mathrm{R}}$ & $\mathrm{MS}_{\mathrm{R}}^{(\mathrm{b})}$ & \\
\hline Total & abcn-1 & $\mathrm{SS}_{\mathrm{T}}$ & & \\
\hline
\end{tabular}

A factorial design of two factors in two levels (low and high) was adopted in order to study the $\mathrm{RhB}$ degradation. The selected factors were the type of treatment (EO or PEO) and the type of supporting electrolyte salt $(\mathrm{NaCl}$ or $\left.\mathrm{Na}_{2} \mathrm{SO}_{4}\right)$ in the same concentration $\left(0.6 \mathrm{~g} \mathrm{~L}^{-1}\right)$, giving a conductivity of $1.3 \mathrm{mS} . \mathrm{cm}^{-1}$ using $\mathrm{NaCl}$ and $1.1 \mathrm{mS}$ $\mathrm{cm}^{-1}$ for $\mathrm{Na}_{2} \mathrm{SO}_{4}$. Table 2 presents the conditions tested considering the factors and respective levels evaluated in the factorial design. The experiment was conducted with two repetitions per set and the execution was randomized. The effects of the treatment and the type of supporting electrolyte on the degradation of $\mathrm{RhB}$ were evaluated by color loss and Total Organic Carbon (TOC) reduction.

The process efficiency for the removal of color and carbon mineralization was calculated from the initial and final absorbance or TOC values and measured according to the formula:

$$
\eta=\left[1-\left(X_{\text {final }} / X_{\text {initial }}\right)\right] \times 100 \%
$$

where $\eta$ is the efficiency and $X$ are the measured values for absorbance or TOC.

Besides the evaluation carried out after $60 \mathrm{~min}$, samples were collected every $15 \mathrm{~min}$ to determine the color loss as a function of time elapsed and then estimate the time required for total color degradation in each tested condition.

Direct photolysis samples were evaluated separately, as a complementary analysis. Samples were collected before and after the treatment $(60 \mathrm{~min})$ in order to determine the molecular absorbance and the TOC. The schematic flowchart in Fig. 2 summarizes the experimental procedures used in this paper.

Table 2. Experimental conditions evaluated in the factorial design.

\begin{tabular}{lcc}
\hline Condition & Treatment & Supporting electrolyte \\
\hline 1 & Eletrooxidation & $\mathrm{NaCl}$ \\
2 & Photoelectrooxidation & $\mathrm{NaCl}$ \\
3 & Eletrooxidation & $\mathrm{Na}_{2} \mathrm{SO}_{4}$ \\
4 & Photoelectrooxidation & $\mathrm{Na}_{2} \mathrm{SO}_{4}$ \\
\hline
\end{tabular}

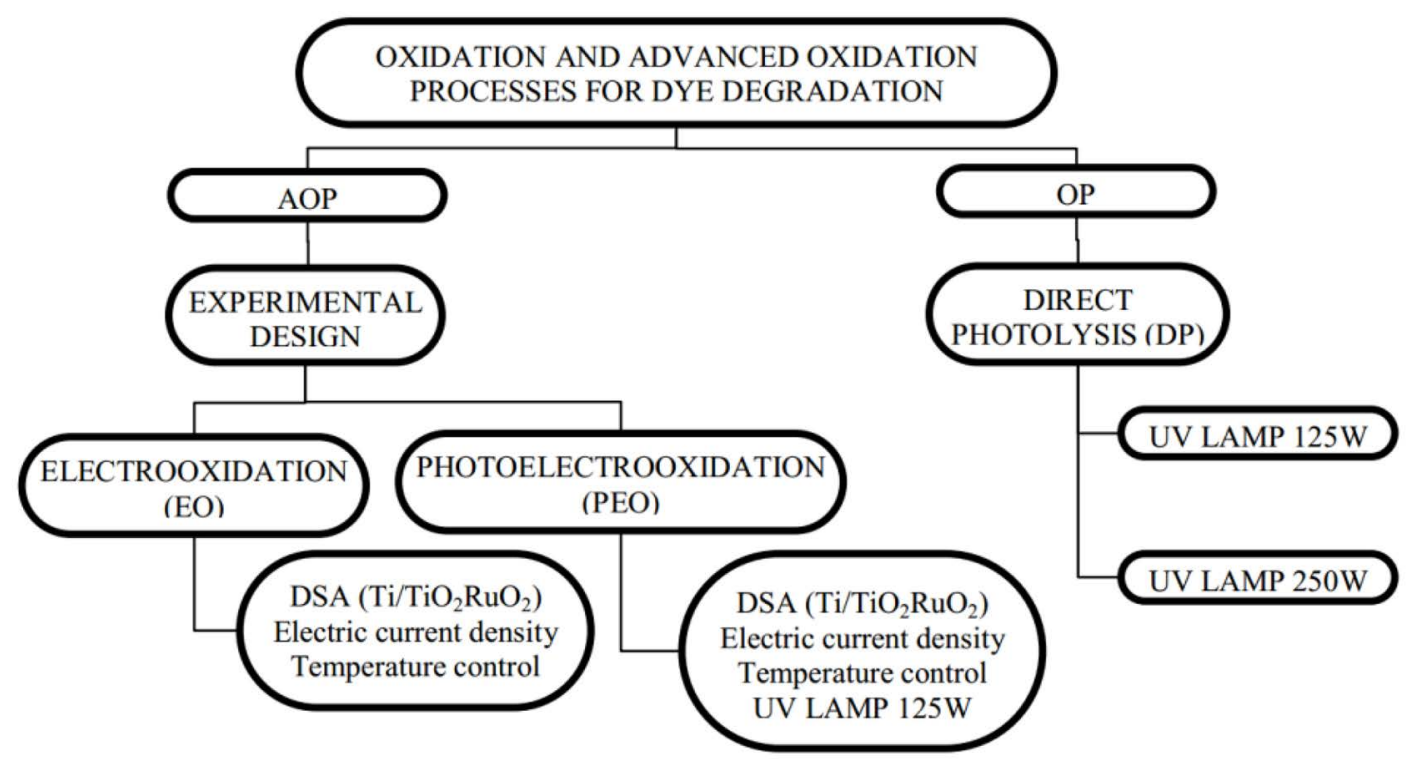

Figure 2. Flowchart of oxidative treatments tested for RhB degradation. 


\section{RESULTS AND DISCUSSION}

\section{Values of molecular UV-VIS absorbance for EO and PEO}

Table 3 shows the results of the absorbance measurements before and after each tested condition. Table A1 presents ANOVA evaluation for the absorbance data.

Fig. 3 shows the main effects of each factor and interactions. The main effects plot represents the system response due to the pure factor setting between low and high levels, as if each factor had been tested isolated; the slope of the line indicates the factor significance for the experimental response, a steep slope means a higher effect. The interaction plot represents the experimental responses due to interactions between factors, i.e., considering that one factor may interfere in the other factor effect according to the level set; parallel lines between factors indicate there is no interaction; the interaction strength increases as the lines become concurrent up to becoming perpendicular.

The factorial experiment shows that the supporting electrolyte seems to be the most significative factor for the removal of color, due to the steep slope of the line. The type of treatment process had little influence on the final result for the absorbance measurement. In addition, the parallelism formed between the two lines in the interaction plot demonstrates that the supporting electrolyte and the treatment process factors did not interact between each other significantly.

With the use of $\mathrm{NaCl}$, there is generation of hypochlorite radical. Its oxidative effect has already been evaluated in research on dye wastewaters (Hasnat et al., 2015; Rosa et al., 2015) and other organic contaminants (Chen et al., 2013) using chlorinated supporting electrodes, where it was supposed that hypochlorite electrochemically generated from chloride oxidation on the electrode surface was responsible for the organic molecule degradation. Chloride ions can be oxidized to form the strong oxidizing species hypochlorite as per the following reactions:

$$
\begin{aligned}
2 \mathrm{Cl}^{-} & \rightarrow \mathrm{Cl}_{2}+2 e^{-} \\
\mathrm{Cl}_{2}+\mathrm{H}_{2} \mathrm{O} & \rightarrow \mathrm{HOCl}+\mathrm{H}^{+}+\mathrm{Cl}^{-} \\
\mathrm{HOCl} & \rightarrow \mathrm{H}^{+}+\mathrm{OCl}^{-}
\end{aligned}
$$

\begin{tabular}{|c|c|c|c|c|c|}
\hline Test & Supporting electrolyte & Treatment & $0 \min ($ a.u. $)$ & $60 \min ($ a.u. $)$ & $\eta^{(a)}(\%)$ \\
\hline A1 & $\mathrm{NaCl}$ & $\mathrm{EO}$ & 2.506 & 0.214 & 91.5 \\
\hline $\mathrm{C} 1$ & $\mathrm{Na}_{2} \mathrm{SO}_{4}$ & EO & 2.505 & 1.926 & 23.1 \\
\hline B1 & $\mathrm{NaCl}$ & PEO & 2.506 & 0.147 & 94.1 \\
\hline D1 & $\mathrm{Na}_{2} \mathrm{SO}_{4}$ & PEO & 2.505 & 2.000 & 22.5 \\
\hline $\mathrm{C} 2$ & $\mathrm{Na}_{2} \mathrm{SO}_{4}$ & $\mathrm{EO}$ & 2.505 & 1.957 & 21.9 \\
\hline D2 & $\mathrm{Na}_{2} \mathrm{SO}_{4}$ & PEO & 2.505 & 1.443 & 42.4 \\
\hline A2 & $\mathrm{NaCl}$ & $\mathrm{EO}$ & 2.506 & 0.141 & 94.4 \\
\hline $\mathrm{B} 2$ & $\mathrm{NaCl}$ & PEO & 2.506 & 0.126 & 95.0 \\
\hline
\end{tabular}

Table 3. Absorbance values and absorbance reduction efficiency in the RhB degradation measured at $554 \mathrm{~nm}$ for different supporting electrolytes and treatment processes.

(a)absorbance reduction efficiency

a)

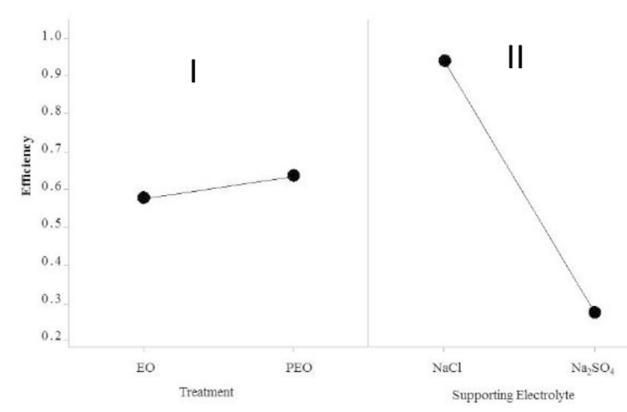

b)

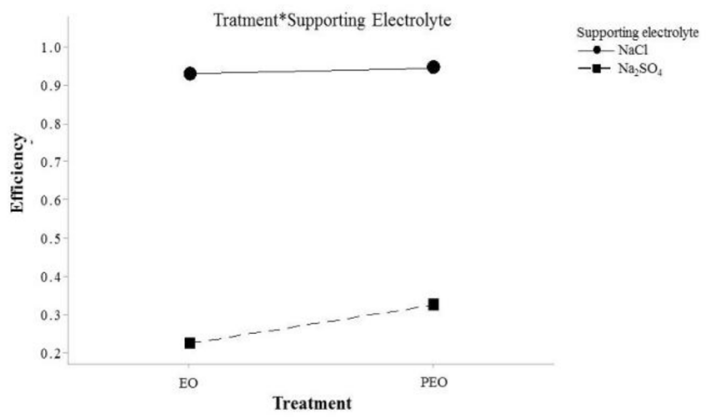

Figure 3. Graphics of the main effects and interactions between factors for the efficiency in the color removal. (a) Medium value of efficiency for each treatment type (I) and for each supporting electrolyte (II); (b) Interactions between each treatment type and the supporting electrolyte. 
The $\mathrm{OCl}^{-}$ion is a strong oxidizing agent, which has the ability to degrade organic molecules through direct and indirect routes. It is therefore expected that dye molecules were degraded chemically, followed by electrochemical generation of $\mathrm{OCl}^{-}$species at the anode surface:

$$
\begin{aligned}
& \mathrm{OCl}^{-}+\mathrm{RhB}^{+} \rightarrow \text { Degraded products } \\
& \left(\mathrm{CO}_{2}+\mathrm{Cl}^{-}+\mathrm{H}_{2} \mathrm{O}+\mathrm{H}^{+}\right)
\end{aligned}
$$

Analyzing the data shown in Table 3, when $\mathrm{NaCl}$ was employed as supporting electrolyte, the decolorization in PEO experiments was slightly higher than in EO. According to Chen et al. (2004), previous research suggested that the photolysis of $\mathrm{HOCl}$ can yield two active oxidants - the chlorine radical $(\mathrm{Cl} \bullet)$ and the hydroxyl radical $(\mathrm{HO} \bullet)$, indicating a synergic effect of $\mathrm{UV} / \mathrm{OCl}$ (Chan et al., 2012).Although a more efficient way of discoloration, the use of chlorinated supporting electrodes may lead to the formation of organochlorinated species, possibly more toxics than the initial contaminant. This is the main drawback for the use of this oxidant (Tedder and Pohland, 2000). That is why sodium sulfate was also evaluated.

Results of absorbance determination with different treatment times are presented in Fig. 4. As can be seen in Fig. 4, the PEO and EO processes performed on the effluent containing $\mathrm{NaCl}$ as supporting electrolyte
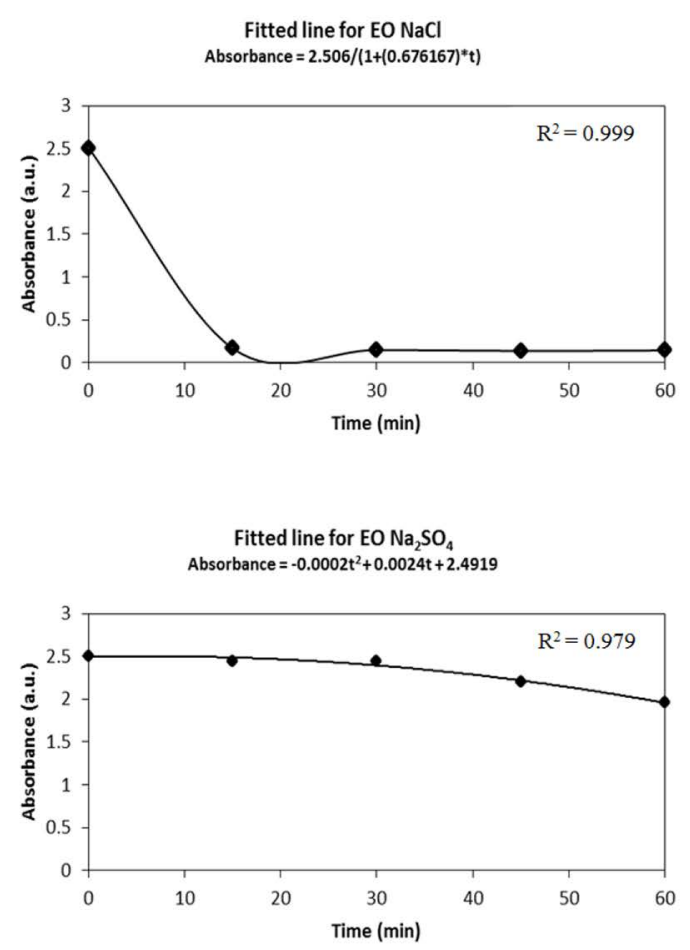

showed an exponential decrease in absorbance, reaching values close to zero for $\mathrm{EO}$ and $\mathrm{PEO}$ between 15 and $30 \mathrm{~min}$ of treatment, respectively. On the other hand, for the processes where $\mathrm{Na}_{2} \mathrm{SO}_{4}$ was the supporting electrolyte, the efficiency of absorbance reduction was around $20 \%$ for EO and PEO, lower than that obtained for the treatment of wastewater with $\mathrm{NaCl}$. Song et al. (2011) compared different electrolyte type on the RhB color removal efficiency during the EO process, indicating similar results, while $\mathrm{NaCl}$ was four times more efficient than $\mathrm{Na}_{2} \mathrm{SO}_{4}$.

When $\mathrm{Na}_{2} \mathrm{SO}_{4}$ was used, the UV radiation seems to show a positive effect. The color removal indicated an attack on the chromophoric group of the dye molecule. Araújo et al. (2015) described a similar result of the positive effect of UV irradiation for RhB. During electrooxidation processes, $\mathrm{HO} \bullet$ radicals are produced (Li et al., 2015) and these oxidant species are transformed into more stable oxidants by combining with other $\mathrm{HO} \cdot$ radicals (Eq. 6) or oxygen (Eq. 7), producing hydrogen peroxide and/or ozone (Sirés et al., 2014).

$$
\begin{gathered}
2 \mathrm{HO} \bullet \rightarrow \mathrm{H}_{2} \mathrm{O}_{2} \\
\mathrm{O}_{2}+2 \mathrm{HO} \bullet \rightarrow \mathrm{O}_{3} \mathrm{H}_{2} \mathrm{O}
\end{gathered}
$$
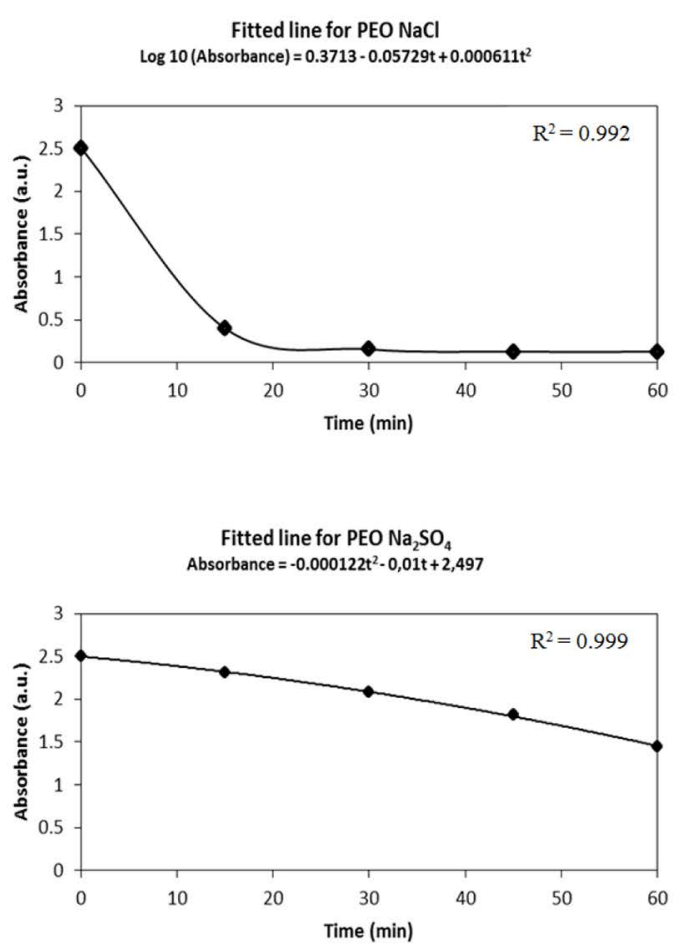

Figure 4. Fit of the experimental points for absorbance measurements of the samples collected during the treatment by EO and PEO for both supporting electrolytes. 
Both ozone and peroxide, during the photoelectrooxidation, can be affected by UV light irradiation, and they can generate the $\mathrm{HO} \bullet$ radical (eq. 8 and 9) (Souza et al., 2014):

$$
\begin{aligned}
\mathrm{H}_{2} \mathrm{O}_{2}+h v & \rightarrow \mathrm{HO} \cdot \\
\mathrm{H}_{2} \mathrm{O}_{2}+\mathrm{O}_{3}+h v & \rightarrow 2 \mathrm{HO} \cdot+\mathrm{O}_{2}
\end{aligned}
$$

These can help to explain the small improvement verified for color removal in the PEO process.

In comparison, the absorbance reduction was faster for the EO treatment than PEO in the presence of $\mathrm{Cl}^{-}$ , but the final absorbance values were very similar, slightly lower for PEO. The decreasing absorbance values are in accordance with the previous discussion about chlorine and UV radiation.

\section{Evaluation of Total Organic Carbon Concentration (TOC)}

Table 4 shows the results for TOC reduction using both advanced oxidation processes and different supporting electrolytes. It can be seen that, although the color was almost completely removed, the organic matter persisted.

Samples from tests A1, C1 and B2 did not indicate a reduction in TOC. On the other hand, the other samples indicated a low TOC reduction. An important factor in these low efficiencies is the very high TOC concentration in the agate dyeing wastewater. The solution contains water, $\mathrm{RhB}$ and ethanol. This alcohol is a small organic molecule, therefore it is possible that the treatment time and the concentration of oxidants agents were not enought to mineralize it completelly. Ethanol degradation can result in various intermediates (Chen et al., 1999).

For solutions containing $\mathrm{RhB}+\mathrm{Na}_{2} \mathrm{SO}_{4}$, UV irradiation does not contribute to improve the TOC removal when current density is applied, according to the studies reported by Araújo et al. (2015) treating $\mathrm{RhB}$, although their solution did not contain ethanol. Table A2 shows the ANOVA values obtained for TOC evaluation.
For the TOC removal efficiency, the ANOVA does not show significant efficiency for any factor or interaction ( $\mathrm{P}$ value $>0.05$ ). The presence of chloride in the solution makes possible the almost complete color degradation. Indeed, the TOC analysis indicated that the organic mineralization was only starting after 60 minutes of treatment, as shown by the low reduction in TOC.

According to Ghernaout et al. (2011), several studies with diferent electrodes for organic compound degradation have indicated that electrodes with low oxygen evolution overpotential (as presented by $\mathrm{RuO}_{2}$ ) allow only a primary oxidation of organic compounds (conversion reaction), but do not perform a complete mineralization due to the accumulation of oxidation intermediates, notably aliphatic acids, which are more stable.

In order to explore the UV irradiation effect, mainly verified for color removal, an additional evaluation was performed.

\section{Fluence (UV Dose)}

The emission characteristics and geometry of the light source are decisive factors for the efficiency of a photochemical reactor. The high pressure mercury vapor lamps used presented an emission spectrum that covered the entire UV region, which benefits the absorption by organic compounds and direct photolysis (emission band in the UV region of $254 \mathrm{~nm}$ ). Additionally, the high pressure mercury vapor lamps favor the excitation of the semiconductor applied in the photoelectrooxidation processes (emission band in the UV region of $365 \mathrm{~nm}$ ).

For the 125 and $250 \mathrm{~W}$ lamps the irradiance that arrived at the electrode through the ultrapure water was 3.14 and $9.68 \mathrm{~mW} . \mathrm{cm}^{-2}$ respectively. Hence, the use of the $250 \mathrm{~W}$ lamp will allow a higher irradiance through the solution. For both lamps (125 and 250 $\mathrm{W})$ the irradiance (assumed equal to the fluence rate) and UV fluence (UV dose) for all studied solutions is indicated in Table 5. The irradiance was measured during 1 hour, and, at the end, some solutions became decolorized, demonstrating again the effect of UV irradiation on $\mathrm{RhB}$ degradation.

Table 4. TOC results for initial $\left(0 \mathrm{~min}-\mathrm{TOC}_{0}\right)$ and final $\left(60 \mathrm{~min}-\mathrm{TOC}_{60}\right)$ samples.

\begin{tabular}{ccccccc}
\hline Order & Test & SupportingElectrolyte & Treatment & {$\left[\mathrm{TOC}_{0}\right]\left(\mathrm{mgL}^{-1}\right)$} & {$\left[\mathrm{TOC}_{60}\right]\left(\mathrm{mgL}^{-1}\right)$} & $\eta(\mathrm{a})(\%)$ \\
\hline $\mathbf{3}$ & $\mathrm{B} 1$ & $\mathrm{NaCl}$ & PEO & 32585 & 29809 & 8.5 \\
$\mathbf{4}$ & $\mathrm{D} 1$ & $\mathrm{Na}_{2} \mathrm{SO}_{4}$ & PEO & 29735 & 27171 & 8.6 \\
$\mathbf{5}$ & $\mathrm{C} 2$ & $\mathrm{Na}_{2} \mathrm{SO}_{4}$ & EO & 32585 & 28216 & 13.4 \\
$\mathbf{6}$ & $\mathrm{N} 2$ & $\mathrm{Na}_{2} \mathrm{SO}_{4}$ & PEO & 29735 & 28166 & 5.3 \\
7 & $\mathrm{NaCl}$ & EO & 32585 & 32363 & 0.7 \\
\hline (a) & TOC reduction efficiency & & & &
\end{tabular}


As seen in Table 5, the irradiance through pure water was more intense than in the samples containing $\mathrm{RhB}$, both using $125 \mathrm{~W}$ and $250 \mathrm{~W}$ lamps. These solutions absorb radiation, what indicates that DP will be favored in order to degrade $\mathrm{RhB}$ and to obtain a decolorized effluent.

\section{Direct photolysis: Evaluation of Color removal and TOC reduction}

Samples were collected in the beggining and at the end of each DP treatment using 125 and $250 \mathrm{~W}$ UVlamps. The absorbance values are indicated in Table 6 .

The data presented indicate that the use of DP applying a $250 \mathrm{~W}$ UV-lamp may be an efficient treatment for decolorization of agate dyeing wastewater, eliminating the need of supporting electrolyte. Absorbance reduction in the DP process for $\mathrm{RhB}$ can be related to the direct interaction between radiation and the organic dye structure, because UV light has relatively high photon energy, which is enough to break chemical bonds in most organic compounds (Li et al., 2015). When the UVVIS absorbance of the effluent with $\mathrm{NaCl}$ is analyzed, the application of a $125 \mathrm{~W} \mathrm{UV-Lamp} \mathrm{and} \mathrm{an} \mathrm{additional}$ time for treatment may generate a decolorized effluent, with a lower cost process. In this case, UV irradiation and chloride media seems to show a synergic effect, favouring the decolorization, as indicated in Fig. 5.

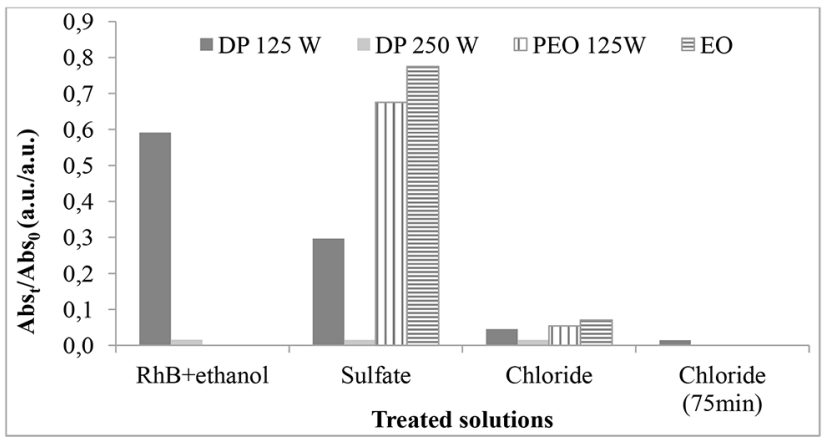

Figure 5. Color removal for treated samples. DP $125 \mathrm{~W}$ and DP $250 \mathrm{~W}$ - direct photolysis using 125 and $250 \mathrm{~W}$ UV-lamps, respectively; PEO $125 \mathrm{~W}$ - photoelectrooxidation using a $125 \mathrm{~W}$ UV-lamp and EO - electrooxidation process.

Fig. 5 summarizes the results of color removal for all oxidation processes. The data was expressed as the ratio between final and initial measured absorbance $\left(\mathrm{Abs}_{\mathrm{t}} / \mathrm{Abs}_{0}\right)$. It is clear that the higher UV irradiation source (DP $250 \mathrm{~W}$ ) showed the more effective color removal, followed by the DP using a $125 \mathrm{~W}$ lamp and $\mathrm{NaCl}$ as supporting electrolyte. PEO and EO were similarly effective for color removal in chloride media, indicating the main effect of supporting electrolyte. All processes were effective for color removal in chloride media, according to previous discussions about chlorinated oxidants.

Table 5. UV Irradiance an UV fluence through pure water and rhodamine-B solutions.

\begin{tabular}{|c|c|c|c|c|c|c|c|c|c|}
\hline & \multirow[b]{2}{*}{ Solutions } & \multicolumn{2}{|c|}{ Water } & \multicolumn{2}{|c|}{ Water $+\mathrm{RhB}+\mathrm{C}_{2} \mathrm{H}_{5} \mathrm{OH}$ (Pure) } & \multicolumn{2}{|c|}{ Pure $+\mathrm{Na}_{2} \mathrm{SO}_{4}$} & \multicolumn{2}{|c|}{ Pure+ $+\mathrm{NaCl}$} \\
\hline & & $\begin{array}{l}\text { Irradiance } \\
\left(\mathbf{m W} \mathbf{c m}^{-2}\right)\end{array}$ & $\begin{array}{l}\text { Fluence } \\
\left(\mathbf{k J ~ m}^{-2}\right)\end{array}$ & $\begin{array}{l}\text { Irradiance } \\
\left(\mathrm{mW} \mathrm{cm}^{-2}\right)\end{array}$ & $\begin{array}{l}\text { Fluence } \\
\left(\mathbf{k J ~ m}^{-2}\right)\end{array}$ & 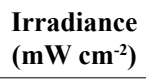 & $\begin{array}{l}\text { Fluence } \\
\left(\mathbf{k J} \mathbf{~ m}^{-2}\right)\end{array}$ & $\begin{array}{l}\text { Irradiance } \\
\left(\mathrm{mW} \mathrm{cm}^{-2}\right)\end{array}$ & $\begin{array}{l}\text { Fluence } \\
\left(\mathbf{k J ~ m}^{-2}\right)\end{array}$ \\
\hline \multicolumn{10}{|c|}{ Time } \\
\hline \multirow{5}{*}{ 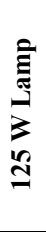 } & 0 min & 3.14 & - & 0.94 & - & 1.34 & - & 1.32 & - \\
\hline & $60 \mathrm{~min}$ & 3.14 & 113.04 & 1.06 & 33.84 & 1.81 & 48.24 & 2.23 & 47.52 \\
\hline & $75 \mathrm{~min}$ & - & - & - & - & - & - & 2.05 & 59.4 \\
\hline & Color Initial & \multicolumn{2}{|c|}{ colorless } & \multicolumn{2}{|c|}{ Pink } & \multicolumn{2}{|c|}{ Pink } & \multicolumn{2}{|c|}{ pink } \\
\hline & Final & \multicolumn{2}{|c|}{ colorless } & \multicolumn{2}{|c|}{ Pink } & \multicolumn{2}{|c|}{ Pink } & \multicolumn{2}{|c|}{ Colorless $^{(a)}$} \\
\hline \multirow{4}{*}{ 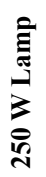 } & 0 min & 9.68 & - & 5.52 & - & 5.37 & - & 4.61 & - \\
\hline & $60 \mathrm{~min}$ & 9.68 & 348.48 & 9.8 & 198.72 & 8.44 & 193.32 & 8.89 & 165.96 \\
\hline & Color Initial & \multirow{2}{*}{\multicolumn{2}{|c|}{$\begin{array}{l}\text { colorless } \\
\text { colorless }\end{array}$}} & \multirow{2}{*}{\multicolumn{2}{|c|}{$\begin{array}{c}\text { Pink } \\
\text { Colorless }\end{array}$}} & \multirow{2}{*}{\multicolumn{2}{|c|}{$\begin{array}{c}\text { Pink } \\
\text { Colorless }\end{array}$}} & \multirow{2}{*}{\multicolumn{2}{|c|}{$\begin{array}{c}\text { pink } \\
\text { colorless }\end{array}$}} \\
\hline & Final & & & & & & & & \\
\hline
\end{tabular}

Table 6. Absorbance values for solutions before and after the treatment by direct photolysis.

\begin{tabular}{lcccc}
\hline Sample & Time & Water $+\mathrm{RhB}+\mathrm{C}_{2} \mathrm{H}_{5} \mathrm{OH}$ (Pure) (a.u.) & Pure $+\mathrm{Na}_{2} \mathrm{SO}_{4}$ (a.u.) & Pure $+\mathrm{NaCl}($ a.u. $)$ \\
\hline Lamp & Initial & 2.535 & 2.532 & 2.533 \\
$\mathbf{1 2 5} \mathbf{~ W}$ & $\mathbf{6 0} \mathbf{~ m i n}$ & 1.389 & 0.751 & 0.114 \\
& $\mathbf{7 5} \mathbf{~ m i n}$ & - & - & 0.037 \\
$\mathbf{2 5 0} \mathbf{~ W}$ & Initial & 2.535 & 2.532 & 2.533 \\
& $\mathbf{6 0} \mathbf{~ m i n}$ & 0.037 & 0.038 & 0.039 \\
\hline
\end{tabular}


In sulfate media, the color removal was more effective for DP using $250 \mathrm{~W}$, followed by DP $125 \mathrm{~W}$, $\mathrm{PEO}$ and EO, that can be related to the fragmentation of the chromophore group of RhB molecule by light irradiation (Ye et al., 2009).

Fig. 6 represents the TOC reduction observed for all oxidation treatment performed on RhB solutions. Photolysis using higher radiation intensity resulted in a more efficient $\mathrm{TOC}$ romoval and $\mathrm{NaCl}$ improved the mineralization process. However, the final TOC values were around 30 gTOC.L L $^{-1}$, a very high concentration for discharge effluents, mainly because of the ethanol concentration.

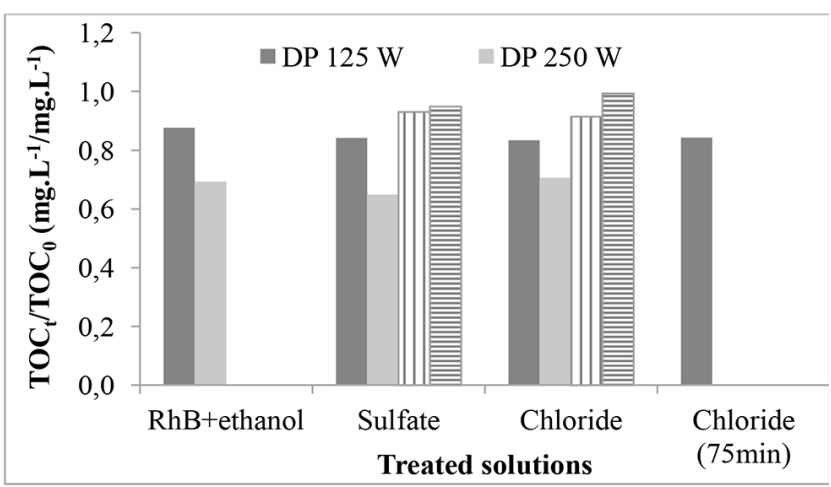

Figure 6. TOC removal for treated samples. DP $125 \mathrm{~W}$ and DP $250 \mathrm{~W}$ - direct photolysis using 125 and $250 \mathrm{~W}$ UV-lamps, respectively; PEO $125 \mathrm{~W}$ - photoelectrooxidation using a $125 \mathrm{~W}$ UV-lamp and EO - electrooxidation process.

The reduction for TOC seems not to be affected by the supporting electrolyte. Comparing PEO and EO, a slight difference was detected, with the best result for PEO in chloride media. Similar behavior was observed for color removal, reinforcing the synergic effect of $\mathrm{UV}$ and electrogenerated oxidants in chloride and sulfate media for color reduction and TOC removal.

\section{Energy consumption evaluation}

An important factor in any treatment system is the energy expenditure associated with each process. In this way, the energetic consumption (kW.h. $\mathrm{kg}^{-1}$ ) associated with the oxidation test performed in this work was calculated according to the follow equation:

$$
\text { Consumption }=\text { U.I.t. } m^{-1}
$$

where $\mathrm{U}=$ potencial $(\mathrm{V}) ; \mathrm{I}=$ current $(\mathrm{A}) ; \mathrm{t}=$ time $(\mathrm{h})$ and $\mathrm{m}=$ mass removed $(\mathrm{kg})$.

For the $\mathrm{EO}$ treatments with $\mathrm{NaCl}$ the consumption was $7.45 \mathrm{kWh} \cdot \mathrm{kg}^{-1} \mathrm{TOC}$, while for the same process using $\mathrm{Na}_{2} \mathrm{SO}_{4}$ as supporting electrolyte the consumption was $1.4 \mathrm{kWh} . \mathrm{kg}^{-1} \mathrm{TOC}$. Although the smallest energetic consumption was verified for $\mathrm{Na}_{2} \mathrm{SO}_{4}$, the best observed effect for the dye degradation was in the EO treatment using $\mathrm{NaCl}$ as supporting electrolyte.

In the PEO process, it was verified that the lamp consumption increases the treatment costs. The median consumption using $\mathrm{NaCl}$ as supporting electrolyte was $37.6 \mathrm{~kW} . \mathrm{h} . \mathrm{kg}^{-1} \mathrm{TOC}$, and using $\mathrm{Na}_{2} \mathrm{SO}_{4}$, the consumption was 46.4 kW.h. $\mathrm{kg}^{-1}$ TOC.

In comparison, photolysis consumption was intermediary, considering the absence of electrodes and electric current. The $125 \mathrm{~W}$ UV-lamp in chloride media consumed around $13 \mathrm{~kW} . \mathrm{h} . \mathrm{kg}^{-1}$ TOC. For the $250 \mathrm{~W}$ lamp, the energy consumption was estimated at $25 \mathrm{~kW} . \mathrm{h} . \mathrm{kg}^{-1} \mathrm{TOC}$.

\section{CONCLUSIONS}

The Advanced Oxidation Processes (AOPs) of electrooxidation (EO) and photoelectrooxidation (PEO), as well as direct photolysis (DP), were evaluated for the treatment of wastewater containing $\mathrm{RhB}$. The three treatment processes removed more than $93 \%$ of total color in 60 minutes when chloride was applied as supporting electrolyte. In 75 minutes, direct photolysis using a 125 W lamp as source of UV radiation (in chloride media) was able to remove $98.5 \%$ of total color. The same result was obtained in 60 minutes by DP with the $250 \mathrm{~W}$ lamp as the source of UV radiation in sulfate and chloride media.

On the other hand, the best result of mineralization was $40 \%$ for direct photolysis with $250 \mathrm{~W}$ in sulfate media. In fact, none of the treatments presented considerable efficiency for TOC removal. Therefore, the expected synergic effect was not observed in the tested treatment conditions for photoelectrooxidation $(125 \mathrm{~W}, 60 \mathrm{~min})$ and electrooxidation (60 $\mathrm{min})$. Thus, direct photolysis may be applied for color removal. However, the efficiency of decolorization is not reflected in an effective degradation of organic matter (TOC). New parameters must be evaluated in order to improve the mineralization of this dye wastewater.

\section{ACKNOWLEDGMENT}

This study was financially supported by CAPES, CNPq, FINEP and FAPERGS.

\section{APPENDIX A}

Table A1 contains ANOVA values from the absorbance measurements. It can be seen that only the supporting electrolyte is significative ( $\mathrm{P}$ value $<0.05$ ). The treatment process is not significative for absorbance reduction ( $\mathrm{P}$ value $>0.05$ ). 
Table A1. ANOVA for the studied factors and interactions effects on the mean absorbance reduction efficiency.

\begin{tabular}{lccccc}
\hline Source & DF & SS & MS & F test & P value \\
\hline Main effects & 2 & 0.8848 & 0.4424 & 87.2 & 0.001 \\
Treatment & 1 & 0.0067 & 0.0067 & 1.33 & 0.314 \\
Supporting electrolyte & 1 & 0.8781 & 0.8781 & 0.68 & 0.000 \\
2nd order interactions & 1 & 0.0035 & 0.0035 & & \\
Treatment vs & & & & 0.65 \\
supporting & & & & \\
electrolyte & 1 & 0.0035 & 0.0035 & & \\
Residual error & 4 & 0.0203 & & & \\
Total & 7 & 0.9086 & & & \\
\hline
\end{tabular}

where: $\mathrm{DF}=$ degrees of freedom; $\mathrm{SS}=$ sum of squares; $\mathrm{MS}=$ mean square

Table A2. ANOVA for the influence of factors on the efficiency of TOC reduction.

\begin{tabular}{|c|c|c|c|c|c|}
\hline Source & DF & SS & MS & $\mathrm{F}$ test & $\mathrm{P}$ value \\
\hline Main effects & 2 & 0.0243 & 0.0122 & 1.90 & 0.265 \\
\hline Treatment & 1 & 0.0043 & 0.0043 & 0.67 & 0.458 \\
\hline Supporting electrolyte & 1 & 0.0200 & 0.0200 & 3.00 & 0.153 \\
\hline 2nd order interactions & 1 & 0.0074 & 0.0074 & 1.14 & 0.345 \\
\hline $\begin{array}{l}\text { Treatment vs } \\
\text { supporting electrolyte }\end{array}$ & 1 & 0.0074 & 0.0074 & 1.14 & 0.345 \\
\hline Residual error & 4 & 0.0257 & 0.0064 & & \\
\hline Total & 7 & 0.0574 & & & \\
\hline
\end{tabular}

where: $\mathrm{DF}=$ degrees of freedom; $\mathrm{SS}=$ sum of squares; $\mathrm{MS}=$ mean square

\section{REFERENCES}

Adeogun, A.I., and Balakrishnan, R.B., Kinetics, isothermal and thermodynamics studies of electrocoagulation removal of basic dye rhodamine B from aqueous solution using steel electrodes. Appl. Water Sci., 7(4), 1711-1723 (2015). doi: 10.1007/s13201-015-0337-4

Araújo, D.M. de,Cotillas, S., Sáez, C., Cañizares, P., Martínez-Huitle, C.A., and Rodrigo, M.A., Activation by light irradiation of oxidants electrochemically generated during Rhodamine B elimination. J. Electroanal. Chem. 757, 144-149 (2015). doi: 10.1016/j.jelechem.2015.09.025

Balakrishnan, P.A., Arunagiri, A., and Rao, P.G., Ozone generation by silent electric discharge and its application in tertiary treatment of tannery effluent. J. Electrostat. 56(1), 77-86 (2002).

Bolton, J.R., Linden, K.G., Standardization of Methods for Fluence (UV Dose) Determination in BenchScale UV Experiments. J. Environ. Eng. (2003).

Buranda, T., Wu, Y., Perez, D., Chigaev, A., Sklar, L.A., Real-Time Partitioning of Octadecyl Rhodamine B into Bead-Supported Lipid Bilayer Membranes Revealing Quantitative Differences in Saturable Binding Sites in DOPC and 1:1:1 DOPC/ SM/Cholesterol Membranes. J. Phys. Chem. B 114, 1336-1349 (2010). doi: 10.1021/jp906648q
Cavicchioli, A., Gutz, I.G.R., O uso de radiação ultravioleta para o pré-tratamento de amostras em análise inorgânica. Quim. Nova 26, 913-921 (2003).

Chan, P.Y., Gamal El-Din, M., Bolton, J.R., A solardriven UV/Chlorine advanced oxidation process. Water Res. 46, 5672-5682 (2012). doi: 10.1016/j. watres.2012.07.047

Chen, J., Liu, M., Zhang, J., Ying, X., Jin, L., Photocatalytic degradation of organic wastes by electrochemically assisted $\mathrm{TiO} 2$ photocatalytic system. J. Environ. Manage. 70, 43-47 (2004). doi: 10.1016/j.jenvman.2003.09.019

Chen, J., Ollis, D.F., Rulkens, W.H., Bruning, H., Photocatalyzed oxidation of alcohols and organochlorides in the presence of native $\mathrm{TiO} 2$ and metallized $\mathrm{TiO} 2$ suspensions. Part (II): Photocatalytic mechanisms. Water Res. 33, 669676 (1999). doi: 10.1016/S0043-1354(98)00262-0

Chen, K.-H., Shih, Y.-J., Huang, Y.-H., Mineralization of citric acid wastewater by photo-electrochemical chlorine oxidation. J. Environ. Manage. 121, 1-5 (2013). doi: 10.1016/j.jenvman.2013.02.011

daSilva, S.W., Klauck, C.R., Siqueira, M.A., Bernardes, A.M., Degradation of the commercial surfactant nonylphenol ethoxylate by advanced oxidation processes. J. Hazard. Mater. 282, 241248 (2015). doi: 10.1016/j.jhazmat.2014.08.014 
Daneshvar, N., Ashassi-Sorkhabi, H., Tizpar, A., Decolorization of orange II by electrocoagulation method. Sep. Purif. Technol. 31, 153-162 (2003).

$\mathrm{Du}, \mathrm{L}$., Wu, J., Hu, C., Electrochemical oxidation of Rhodamine $\mathrm{B}$ on $\mathrm{RuO} 2-\mathrm{PdO}-\mathrm{TiO} 2 / \mathrm{Ti}$ electrode. Electrochim. Acta 68, 69-73 (2012). doi: 10.1016/j. electacta.2012.02.030

Ghernaout, D., Naceur, M.W., Aouabed, A., On the dependence of chlorine by-products generated species formation of the electrode material and applied charge during electrochemical water treatment. Desalination 270, 9-22 (2011). doi: 10.1016/j.desal.2011.01.010

Golimowski, J., Golimowska, K., UV-photooxidation as pretreatment step in inorganic analysis of environmental samples. Anal. Chim. Acta 325, 111-133 (1996).

Hasnat, M.A., Safwan, J.A., Islam, M.S., Rahman, Z., Karim, M.R., Pirzada, T.J., Samed, A.J., Rahman, M.M., Electrochemical decolorization of Methylene blue at $\mathrm{Pt}$ electrode in $\mathrm{KCl}$ solution for environmental remediation. J. Ind. Eng. Chem. 21, 787-791 (2015). doi: 10.1016/j.jiec.2014.04.013

Kaur, H., Kaur, R., Removal of Rhodamine-B dye from aqueous solution onto Pigeon Dropping: Adsorption, Kinetic, Equilibrium and Thermodynamic studies. (2014)

Li, G., Zhu, W., Chai, X., Zhu, L., Zhang, X., Partial oxidation of polyvinyl alcohol using a commercially available DSA anode. J. Ind. Eng. Chem. 31, 55-60 (2015). doi: 10.1016/j.jiec.2015.05.042

Martín de Vidales, M.J., Mais, L., Sáez, C., Cañizares, P., Walsh, F.C., Rodrigo, M.A., Rodrigues, C.A., León, C.P., Photoelectrocatalytic oxidation of methyl orange on a $\mathrm{TiO} 2$ nanotubular anode using a flow cell. Chem. Eng. Technol. 39, 135-141 (2016). doi: 10.1002/ceat.201500085

Massacci, P. (Ed.), Proceedings of the XXI International Mineral Processing Congress, 1st ed. ed, Developments in mineral processing. Elsevier, Amsterdam ; New York. (2000)

Montgomery, D.C., Introduction to Statistical Quality Control, 6th ed. Jhon Wiley and Sons, Inc.(2009)

Oller, I., Malato, S., Sánchez-Pérez, J.A., Combination of Advanced Oxidation Processes and biological treatments for wastewater decontamination-A review. Sci. Total Environ. 409, 4141-4166 (2011). doi: 10.1016/j.scitotenv.2010.08.061

Panizza, M., Kapalka,A., Comninellis, C., Oxidation of organic pollutants on BDD anodes using modulated current electrolysis. Electrochim. Acta 53, 22892295 (2008). doi: 10.1016/j.electacta.2007.09.044
Pelegrino, R.L., Di Iglia, R.A., Sanches, C.G., Avaca, L.A., Bertazzoli, R., Comparative study of commercial oxide electrodes performance in electrochemical degradation of organics in aqueous solutions. J. Braz. Chem. Soc. 13, 60-65 (2002).

Pinhedo, L., Pelegrini, R., Bertazzoli, R., Motheo, A.J., Photoelectrochemical degradation of humic acid on a (TiO2) $0.7(\mathrm{RuO} 2) 0.3$ dimensionally stable anode. Appl. Catal. B Environ. 57, 75-81 (2005). doi: 10.1016/j.apcatb.2004.10.006

Pizzolato, T.M., Carissimi, E., Machado, E.L., Schneider, I.A.H., Colour removal with $\mathrm{NaClO}$ of dye wastewater from an agate-processing plant in Rio Grande do Sul, Brazil. Int. J. Miner. Process. 65, 203-211 (2002).

Rodrigues, C.S.D., Madeira, L.M., Boaventura, R.A.R., Optimization of the azo dye Procion Red H-EXL degradation by Fenton's reagent using experimental design. J. Hazard. Mater. 164, 987994 (2009). doi: 10.1016/j.jhazmat.2008.08.109

Rodrigues, M.A.S., Amado, F.D.R., Xavier, J.L.N., Streit, K.F., Bernardes, A.M., Ferreira, J.Z., Application of photoelectrochemicalelectrodialysis treatment for the recovery and reuse of water from tannery effluents. J. Clean. Prod. 16, 605-611 (2008). doi: 10.1016/j.jclepro.2007.02.002

Rosa, J.M., Fileti, A.M.F., Tambourgi, E.B., Santana, J.C.C., Dyeing of cotton with reactive dyestuffs: the continuous reuse of textile wastewater effluent treated by Ultraviolet / Hydrogen peroxide homogeneous photocatalysis. J. Clean. Prod. 90, 60-65 (2015). doi: 10.1016/j.jclepro.2014.11.043

Selcuk, H., Bekbolet, M., Photocatalytic and photoelectrocatalytic humic acid removal and selectivity of $\mathrm{TiO} 2$ coated photoanode. Chemosphere 73, 854-858 (2008). doi: 10.1016/j. chemosphere.2008.05.069

Simond, O., Schaller, V., Comninellis, C., Theoretical model for the anodic oxidation of organics on metal oxide electrodes. Electrochim. Acta 42, 2009-2012 (1997).

Sirés, I., Brillas, E., Oturan, M.A., Rodrigo, M.A., Panizza, M., Electrochemical advanced oxidation processes: today and tomorrow. A review. Environ. Sci. Pollut. Res. 21, 8336-8367 (2014). doi: 10.1007/s11356-014-2783-1

Song, Y., Kim, D., Park, Y., Statistical optimization of Rhodamine B removal by factorial design using reaction rate constant in electrochemical reaction. Korean J. Chem. Eng. 28, 156-163 (2011). doi: 10.1007/s11814-010-0361-x 
Souza, F.L., Sáez, C., Cañizares, P., Motheo, A.J., Rodrigo, M.A., Coupling photo and sono technologies to improve efficiencies in conductive diamond electrochemical oxidation. Appl. Catal. B Environ. 144, 121-128 (2014). doi: 10.1016/j. apcatb.2013.07.003

Szpyrkowicz, L., Kelsall, G.H., Kaul, S.N., De Faveri, M., Performance of electrochemical reactor for treatment of tannery wastewaters. Chem. Eng. Sci. 56, 1579-1586 (2001).

Tedder, D.W., Pohland, F.G. (Eds.), Emerging technologies in hazardous waste management 8. Kluwer Academic/Plenum Publishers, New York. (2000)
Torres, J.D., Faria, E.A., SouzaDe, J.R., Prado, A.G.S., Preparation of photoactive chitosanniobium (V) oxide composites for dye degradation. J. Photochem. Photobiol. A Chem. 182, 202-206 (2006). doi: 10.1016/j.jphotochem.2006.02.027

Wang, G.-S., Chen, H.-W., Kang, S.-F., Catalyzed UV oxidation of organic pollutants in biologically treated wastewater effluents. Sci. Total Environ. 277, 87-94 (2001).

Ye, Z.L., Cao, C.Q., He, J.C., Zhang, R.X., Hou, H.Q., Photolysis of organic pollutants in wastewater with $206 \mathrm{~nm}$ UV irradiation. Chinese Chem. Lett. 20, 706-710 (2009). doi: 10.1016/j. cclet.2008.12.033 